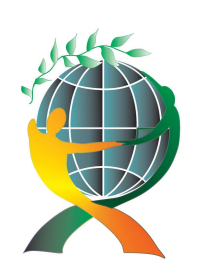

\author{
(online) $=$ ISSN $2285-3642$ \\ ISSN-L = $2285-3642$ \\ Journal of Economic Development, Environment and People \\ Volume 5, Issue3, 2016 \\ URL: http://jedep.spiruharet.ro \\ e-mail: office jedep@spiruharet.ro
}

\title{
Protection of Intellectual Property and its Economic Aspects
}

\author{
Lenka Pelegrinová ${ }^{1}$ and Martin Lačný \\ ${ }^{1}$ VúB Leasing, a.s. \\ ${ }^{2}$ Institute of Political Sciences, Faculty of Arts, University of Prešov
}

\begin{abstract}
Intellectual property, as intangible assets, is classified in most countries under the definitions of the TRIPS Agreement and PCT according to the manner of its protection. This article presents results of an analysis of the relationship between the protection of intellectual property rights at certain globalization level and verification of their influence on economic indicators in the selected countries of the research sample - 32 countries of a similar intellectual property protection system under the PCT. An examination of the level of globalization as a quantitative marker was enabled by the KOF Index of Globalization. Terms and data with the cross-sections enabled to test the 352 objectives through the application of a non-parametric modeling statistical method - panel data regression with the effect of random cross-sectional variables. The conclusions show that there is a statistically significant probability of the relation between the quantity of registered patents and the level of gross domestic product, gross domestic product per capita and adjusted net national income.
\end{abstract}

Keywords: Intellectual property protection, Patent Cooperation Treaty, KOF Index of Globalization, panel data.

JEL Codes: F40, K20, O34

\section{Introduction}

Intellectual property is a relatively new kind of property ownership in its intangible form. It is an ownership resulting from intellectual activity and may relate to artistic activity, a database of information, product and service innovations as well as microorganisms and biological processes. The history of intellectual property globalization is linked with the first legislation under which the industrially developed countries in the 19th century sought to enforce patents and copyright in pursuit of their economic growth and protection of their own cultural autonomy. The legislation passed at the Paris Convention for the Protection of Industrial Property (1883) and the Berne Convention for the Protection of Literary and Artistic Works (1886), enabled the industrially developed countries to build up the lead and also mark the beginning of the emergence of a secondary market for intellectual property.

In terms of the institutional level of globalization in the area of intellectual property there are, especially, two international organizations, the World Trade Organization (WTO) and the World Intellectual 




\author{
(online) $=$ ISSN $2285-3642$ \\ ISSN-L = $2285-3642$ \\ Journal of Economic Development, Environment and People \\ Volume 5, Issue3, 2016 \\ URL: http://jedep.spiruharet.ro \\ e-mail: office jedep@spiruharet.ro
}

Property Organization (WIPO), that create basic legislative framework for the signatory states, which means the majority of the countries in the world. The WTO covers commercial and legal aspects of intellectual property under the Agreement on Trade-Related Aspects of Intellectual Property Rights (TRIPS).

At the global level in the area of intellectual property the WIPO, one of the 17 specialised agencies of the United Nations (UN), functions especially under the Patent Cooperation Treaty (PCT). The TRIPS Agreement and the PCT, including supplements and amendments, provide a kind of a global framework for protection of intellectual property rights. The rules and definitions of the two treaties regulate protection of intellectual property at regional, national and international level, while the other international treaties are effective in the area of intellectual property further added and specify the global environment in which develops a secondary market for intellectual property, as intangible assets.

\title{
2. Brief review of literature on intellectual property and its protection
}

First of all, it is necessary to correctly understand and work with the terms in the field to understand the idea of globalization of intellectual property. The term intellectual property is understood from three different perspectives (Beháňová, 2008):

- as a subject matter, i.e. copyright, patents, trademarks, etc.;

- as the content of rights, i.e. a set of creator's subjective entitlements to the result of creative intellectual activity; and

- as laws, i.e. a group of laws that deal with legal regulation of relationships among actors.

Lack of unity of the understanding and interpretation of results is found in disharmony of their interpretation when considering or define the quantitative and qualitative properties. The general public but also many authors focusing on the issue refer to the term intellectual property as result of creative intellectual activity. They understand intellectual property as a subject and as a right as well.

However, it is important to realize the essential difference between the result of creative intellectual activity, which is subsequently transformed into an intangible idea, artistic work, invention, knowledge, and the intellectual property. The term property suggests that there is a certain legal relationship that is being developed under the subjective right. The subjective right in this case is an opportunity for an individual to claim their title. This right is, or should be, guaranteed by the objective right that is given by a set of laws regulating the area of intellectual property.

Intellectual property is a way of protecting any innovative ideas, whether of technical or artistic character. Such an idea or invention has a specific value for different parties with a possibility to get engaged in the process of its implementation. The protection of intellectual property in various forms is an instrument that should simplify to get a grip on an intangible idea that without being implemented does not have the same value as the outcome of its implementation. The protection of intellectual property enables creative thinkers and inventors to transform an intangible idea into a marketable item, while a higher authority guarantees the protection of their idea in the same way as in case of tangible assets. 
(online) $=$ ISSN $2285-3642$

ISSN-L = $2285-3642$

Journal of Economic Development, Environment and People

Volume 5, Issue3, 2016

URL: http://jedep.spiruharet.ro

e-mail: office jedep@spiruharet.ro

Intellectual property rights are, according to the WIPO, those rights given to persons for creations of their intellectual activity. Intellectual property refers to the products of thinking as inventions, literary and artistic works, symbols, names, pictures or designs that have industrial utility. Their value depends on their usefulness and quality of information as well as on legal protection provided. The protection of intellectual property limits the use of products of intellectual activity that have a commercial value by third parties.

The WIPO draws a distinction between the two following branches of intellectual property:

a) Industrial property - inventions (patents), trademarks, industrial designs, geographical indications of origin etc; and

b) Copyright - literary and artistic works (novels, poetry, plays, films, musical works, photographic works, works of drawing, painting, sculpture, architecture, etc.), performing artists in their performances, producers of sound recordings and recordings of radio and television organizations, computer programmes (open or closed source software).

The WTO, under the TRIPS Agreement, defines intellectual property as all categories of intellectual property that are the subject of its scope, namely, copyright and related rights, trademarks, geographical indications, industrial designs, patents, layout-designs (topographies) of integrated circuits, and protection of undisclosed information (trade secrets).

Copyright is, to some extent, a questionable category of intellectual property protection since its establishment and is directly linked with the creator and the time of its creation. The copyright owner is an individual who has been the creator of the work since it was created and the owner's rights remain even after their death. In comparison to industrial rights, copyright cannot be protected in the same way, i.e. by registering the right with an institution that looks after any matters in relation to protection of intellectual property. In many cases it is not possible to restrict the use of copyright protected works by third parties, for example, if they indicate the originator of copyright or use it for personal purposes. For such reasons it is not possible to quantify intellectual property in the form of copyright.

The case of computer software is a specific issue in intellectual property protection. In certain countries, for instance, the USA, Australia, New Zealand or Japan, computer software is protected by patents, in contrast to the attitude of European countries in which software is the subject of copyright. Computer programmes indicate a significant problem about enforcing the protection of intellectual property rights. The definitions of their individual categories allow different ways of protection in different countries, which complicates any efforts to harmonise national legislations.

The globalization of intellectual property is a penetration of the globalization process into the area of intellectual property rights. Intellectual property rights have been part of the internationalisation and 


\author{
(online) $=$ ISSN $2285-3642$ \\ ISSN-L = $2285-3642$ \\ Journal of Economic Development, Environment and People \\ Volume 5, Issue3, 2016 \\ URL: http://jedep.spiruharet.ro \\ e-mail: office jedep@spiruharet.ro
}

globalization process since the 19th century. At first, the globalization process of intellectual property unfolded in the form of elevated protection of intellectual property in the developed countries that endeavoured to maintain their lead in the development. However, this phenomenon has become more intense in the recent decades, in particular because of entities shifting from tangible assets to intangible assets in the form of intellectual property.

Intellectual property in global governance implicates virtually all aspects of economic globalization and its intricate relationship with global normative and political governance. In the context of global governance, intellectual property regulation implicates an unfolding, complex regime interaction, given the indeterminate nature of technological evolution (Oguamanam, 2011, p. 196-197). The globalization process of intellectual property is currently focusing on harmonisation of procedures and legislation for protection of intellectual property rights in the form of agreements, treaties and declarations effective 'worldwide'. However, to contain all aspects of intellectual property rights protection within the global regime is becoming increasingly more difficult at the current dynamics of technological development. Especially two organizations, the WTO and WIPO, are pursuing it but their perspective on protection of intellectual property differs in their interests and objectives. While the interests of one organization can be identified rather as economic with a significant influence of international lobbying, the interests of the latter lie rather in efforts to harmonise procedures and legislation.

There is also a significant difference in the position of the state within the two international organizations. The World Intellectual Property Organization (WIPO) does not significantly interact with the position of the state. Its member states are bound by international treaties with the objective to harmonise procedures for intellectual property protection to gain advantages resulting from it. In this context we can talk about the sovereign position of the state since there is no higher authority that can effectively sanction states that do not comply with treaties. However, the situation is different within the World Trade Organization (WTO) that has effective sanctions, especially, of economic character. This is a case of a partial loss of the sovereign position of the state, in which the state has to share it with an international organization that is controlled by economically powerful entities.

Concerning the global implications of intellectual property for states, individuals, society and different types of business entities, the actors in the globalization process are discussing them at different levels. The proponents of global intellectual property rights argue that authors of works are entitled to exercise their rights against a product of their own intellectual activity. Protection of their products motivates them towards further innovative activity, which eventually results in the prosperity of the entire society. Scholars appeal on a need for creating efficient protection for specific products on a worldwide scale for reasons of 'preserving cultural, social and societal values' (Hajnalová, 2009; Dudinský and Dudinská, 2012).

Another argument in favour of global intellectual property rights is an emerging secondary market for intellectual property, in which, according to liberalistic principles, all actors may prosper. Beháňová 


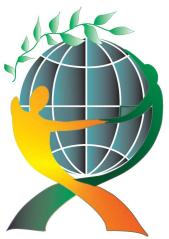

\author{
(online) $=$ ISSN $2285-3642$ \\ ISSN-L = $2285-3642$ \\ Journal of Economic Development, Environment and People \\ Volume 5, Issue3, 2016 \\ URL: http://jedep.spiruharet.ro \\ e-mail: office jedep@spiruharet.ro
}

(2008), for example, warns that multinational corporations move advanced technologies and products and increase rates of their investment in markets in developing economies where their intellectual property is sufficiently protected. The authors believe that especially this factor encourages less developed economies to grow faster. This opinion is supported by Dobřichovský (2004) who, in his publication, gives evidence that intellectual property is one of the factors that positively influence economic growth. The global protection of intellectual property rights creates, according to the authors, an instrument to encourage and stimulate creativeness and innovations.

However, the opponents of global intellectual property rights point out conflicts in relation to protection of intellectual property as well as problems that additionally arise from its globalization. The protection of intellectual property leads, according to the opponents, to stagnation while the registered authors often seize products that were created due to knowledge transferred in the given culture. The scope of intellectual property rights allows their protection for the benefit of an individual, even though the entire society, its culture, knowledge, know-how, or natural conditions have merits in relation to the product. At the same time, this legally allows to set up monopolies that deform the market. Monopolies pose a threat mainly to industries with high research and development costs, where many enterprises focus on increasing profits from their own innovation while restricting innovative capacities of other enterprises (Archibugi and Filippetti, 2010).

Apart from general disagreement in exercising intellectual property rights the opponents also focus on the system of their implementation on a global scale through international organizations and treaties. The main comments criticizing the globalization instruments of intellectual property, for example, the TRIPS Agreement, may be summed up in a substantial inequality of members that is accepted by the theory of economic rationalism and Marxist theories as well (Baylis and Smith, 2008). On the other hand, for example, C. Juma (1999), who is against such arguments, draws attention to the fact that many developing countries perceive the globalization of intellectual property as negative because international treaties, such as the TRIPS Agreement, influence their ability to use technological knowledge for development of targets beneficial to the public, such as health, nutrition and environmental protection. However, they suggest that such adverse implications should be solved in the form of expanded protection regime of intellectual property, in order to include products and sources provided by developing countries which could increase their share in the international market.

We decided to confront opinions of different authors in our own analysis linked to objective statistical methods for verifying the relationship between economic indicators and indicators of globalization and protection levels of intellectual property in selected countries.

\title{
3. Purpose, Objectives and Methodology
}




\author{
(online) $=$ ISSN $2285-3642$ \\ ISSN-L = $2285-3642$ \\ Journal of Economic Development, Environment and People \\ Volume 5, Issue3, 2016 \\ URL: http://jedep.spiruharet.ro \\ e-mail: office jedep@spiruharet.ro
}

Regarding the different viewpoints of the authors on the protection of intellectual propriety in the age of globalization, we focused our research in the direction of underlying assumptions of our reflections . The system of intellectual property protection is a result of international treaties and conventions that reached the global level through international organizations, such as WTO and WIPO. Thus, we can draw the logical conclusion that the intensification of intellectual property protection and globalization are interconnected processes.

Similarly, we assume that if protection of intellectual property is a result of innovative activity in a country, while its increased protection is attractive to enterprises and investment, the increased protection of intellectual property will also influence national economies. In the area of the protection of intellectual property rights the state acts as an authority, declaring protection of intellectual property rights within creating a legal framework for protection and enforceability of such rights. Therefore, we assume that the state has higher expenditure for developing and operating the entire protection system of intellectual property rights (including personal and operating costs or membership fees in international organizations), than the fees for registration of intellectual property rights are able to cover. This way the state does not protect the public welfare but rather private interest. Therefore, we assume that protection of intellectual property should also have secondary benefits for the state as an investor, for example, in the form of a positive influence on economic development of the country.

The main objective of our analysis is to find out a relationship between the globalization level and the protection of intellectual property rights and verify their influence on economic indicators in the selected countries of the research sample, which means to verify the relations between the variables specified below.

Intellectual property as assets in intangible form is classified in most countries under the definitions of the TRIPS Agreement and PCT according to the manner of its protection. Only four forms of protection of intellectual property that we are able to identify in different countries and objectively find out the quantity of registered inventions, are relevant for our research. These include, in particular, patents, trademarks, industrial design and utility models. These four forms of intellectual property protection may be registered by filing an international PCT application. The other categories of intellectual property may be registered in a traditional manner with national and international patent offices, while the validity of such applications is geographically limited.

For our research it was also necessary to quantify variables determined for verification of mutual relations and connections, while it is necessary to restrict the system of intellectual property protection to compare individual countries. We have chosen a research sample consisting of countries with similar intellectual property protection systems that allow registration of intellectual property under the PCT. We excluded from the comparison the countries that did not allow comparing all the forms of protection under the PCT - meaning through patents, trademarks, designs and utility models, as well as the countries whose data were not available. For the sample we managed to get 32 countries of a similar intellectual property 


\author{
(online) $=$ ISSN $2285-3642$ \\ ISSN-L = $2285-3642$ \\ Journal of Economic Development, Environment and People \\ Volume 5, Issue3, 2016 \\ URL: http://jedep.spiruharet.ro \\ e-mail: office jedep@spiruharet.ro
}

protection system under the PCT.The research sample includes countries (in alphabetical order): Armenia, Australia, Belarus, Brazil, Bulgaria, Czech Republic, China, Denmark, Estonia, Philippines, Greece, Georgia, Japan, South Korea, Hungary, Mexico, Moldavia, Germany, Peru, Poland, Portugal, Austria, Russia, Slovak Republic, Slovenia, Spain, Italy, Thailand, Turkey, Ukraine, Uzbekistan, Vietnam. We have collected the data on quantities of registered forms of intellectual property from WIPO databases that are available to the public.

We obtained macro-economic data from WTO and World Trade Bank databases according to the selection of countries in the research sample. We primarily focused on the following indicators of economic prosperity of countries:

1. ANNI = adjusted net national income in USD;

2. GDP = gross domestic product in USD;

3. GDP_PC = gross domestic product per capita in USD;

4. FDI = foreign direct investment, net inflow in \% of the GDP; and

5. $S=$ gross domestic savings in $\%$ of the GDP.

Along with the economic indicators we also studied the relation between the quantity of registered intellectual property and the KOF globalization index. The KOF globalization index was first presented to scholars in 2002, and was updated in 2012 to its current version. The KOF globalization index is available on an annual basis for 208 countries for the period of 1970-2010. The authors of the index define globalization as a process of creating networks and relations among actors across the continents mediated through a variety of flows including people, information, ideas, capital, products and services. Globalization is a process that erodes national boundaries, integrates national economies, cultures, technologies and governance and produces complex relations of mutual interdependence (KOF Index of Globalization, 2012).

In addition to the basic theoretical and logical methods, such as comparison, analysis, synthesis and deduction, we mainly used a non-parametric statistical regression method of panel data analysis using EViews to reach our objective. The method is suitable for testing the hypotheses specified below in Section A. in case of multidimensional data (time and space dimension). Panel regression allows us to verify the assumption of the relation between the quantity of registered intellectual property as an explanatory variable and explaining variables (ANNI, GDP, GDP_PC, FDI, S, KOF), while some of them were adjusted by natural logarithm.

\title{
4. Results
}




\author{
(online) $=$ ISSN $2285-3642$ \\ ISSN-L = $2285-3642$ \\ Journal of Economic Development, Environment and People \\ Volume 5, Issue3, 2016 \\ URL: http://jedep.spiruharet.ro \\ e-mail: office jedep@spiruharet.ro
}

Our analysis is focused on finding a relation between selected variables including indicators of intellectual property protection levels, macroeconomic indicators and the indicator of globalization level. With respect to the time perspective we focused on the period of 2000-2010, which is an 11-year crosssection of the development in the selected countries. Consequently, the time and cross-sectional data enabled to test 352 objections by applying a non-parametric statistical method - panel data regression with the effect of random cross-sectional variables.

The verification of statistical hypotheses was carried out at the significance level $\alpha$ set to 0.05 . To accept the statistical hypothesis we consider as standard if the P-value (probability level) is smaller than the significance level $\alpha$. TheP-value represents the probability that the test statistic, under the assumption that the null hypothesis is true, will reach a value at least as extreme as the value computed from the sample. If the $P$-value was higher than $\alpha$, the relation determined through testing could only be a random result. The smaller the $P$-value is, the more probable the rejection of the null hypothesis $\mathrm{H}_{0}$ is. The null hypothesis represents an independence of variables and is formulated differently from alternative hypotheses. In our research we formed alternative hypotheses H1-H6 (See the following Determination of research hypotheses section).

On the basis of testing the formed hypotheses in EViews in Section B., we'll be able to prove or reject the scientific hypotheses related to the objective of our research. To verify statistical hypotheses, through the Hausman specification test, we determined the suitability of the use of the random effects model (REM) that assumes random distribution of individual absolute members for cross-sectional data.

Determination of research hypothesesH1 - H6:

$\mathrm{H} 1:$ There is a statistically significant dependence between the quantity of registered intellectual property (IP) and the amount of adjusted net national income (ANNI).

$\mathrm{H} 2$ : There is a statistically significant dependence between the quantity of registered intellectual property (IP) and the amount of gross domestic product (GDP).

H3: There is a statistically significant dependence between the quantity of registered intellectual property (IP) and the amount of gross domestic product per capita (GDP_PC).

$\mathrm{H} 4:$ There is a statistically significant dependence between the quantity of registered intellectual property (IP) and the amount of foreign direct investment (FDI).

H5: There is a statistically significant dependence between the quantity of registered intellectual property (IP) and the amount of gross domestic savings (S).

H6: There is a statistically significant dependence between the quantity of registered intellectual property (IP) and the value of the globalization index (KOF). 


\author{
(online) $=$ ISSN $2285-3642$ \\ ISSN-L = $2285-3642$ \\ Journal of Economic Development, Environment and People \\ Volume 5, Issue3, 2016 \\ URL: http://jedep.spiruharet.ro \\ e-mail: office jedep@spiruharet.ro
}

The formulation of the hypotheses was based on the assumption that economically developed countries prefer a stronger protection regime of intellectual property rights. Thus, we assume that the quantity of intellectual property registered under the PCT is related to the amount of macroeconomic indicators. The levels of ANNI, GDP, GDP_PC, FDI and S should have a growing trend if the quantity of registered patents, trademarks, utility models and designs increases. Under the same conditions we assume that in the countries with a higher level of the KOF globalization index, i.e. in case of a more open globalization process, there will be a higher quantity of registered intellectual property.

Verification of hypotheses - the statistical hypotheses formed in the previous chapter were tested by panel data regression in EViews, and in the process we used a random effects model and the significance level $\alpha$ set to $0.05(5 \%)$. The testing of the statistical hypotheses was based on the original assumptions that showed a link between the quantity of intellectual property registered under the PCT and the level of globalization and economic indicators of countries. Table 1 illustrates the results of panel data regression.

\begin{tabular}{|c|c|c|c|c|}
\hline \multicolumn{5}{|c|}{$\begin{array}{l}\text { Dependent Variable: ID } \\
\text { Method: Panel EGLS (Cross-section random effects) } \\
\text { Cross-sections included: } 32 \\
\text { Total panel (balanced) observations: } 352\end{array}$} \\
\hline Variable & Coefficient & Std. Error & t-Statistic & Prob. \\
\hline ANNI & $-4.03 E-07$ & 3.05E-07 & -1.319415 & 0.1879 \\
\hline GDP & $3.84 \mathrm{E}-07$ & 4.89E-07 & 0.784904 & 0.4331 \\
\hline GDP_PC & 2.025286 & 1.225050 & 1.653227 & 0.0992 \\
\hline FDI & -745.6848 & 3168.176 & -0.235367 & 0.8141 \\
\hline$S$ & -1242.678 & 4456.482 & -0.278847 & 0.7805 \\
\hline KOF & 70345.13 & 85821.60 & 0.819667 & 0.4130 \\
\hline
\end{tabular}

Table 1: The results of IP panel regression (own calculation)

In the tested model we computed a test statistic with the relevant distribution of probability $P$. The $P$-value is a probability that the relation between the observed variables is a random result of an incorrectly chosen sample for testing. The P-value represents a probability of rejecting the null hypothesis, where the significance level $\alpha$ is crucial. It is possible to reject the null hypothesis and thus not to reject the alternative hypotheses, if $P<\alpha$. Otherwise, if $P \geq \alpha$, we cannot reject the null hypothesis.

Concerning the determination of the seven alternative hypotheses we cannot prove if there is an existence of a statistically significant dependence between the observed variables. Thus, we cannot reject the null hypotheses that assume a non-existence of the relationship between the quantity of registered intellectual property, chosen economic indicators and globalization index. Only the $\mathrm{H} 3$ result is approaching an acceptable result; $\mathrm{H} 3$ cannot be proved, but despite that, the result suggests a small probability of a random result when verifying the existence of the relation between the quantity of registered intellectual 


\author{
(online) $=$ ISSN $2285-3642$ \\ ISSN-L = $2285-3642$ \\ Journal of Economic Development, Environment and People \\ Volume 5, Issue3, 2016 \\ URL: http://jedep.spiruharet.ro \\ e-mail: office jedep@spiruharet.ro
}

property and gross domestic product per capita. This element could, to a certain sense, indicate the assumption of the authors, who believe that a stronger protection regime of intellectual property, also having an effect on the quantity of registered intellectual property, stimulates the growth of GDP per capita.

Alternatively, for the purpose of the experiment we narrowed the explained variable that was represented by intellectual property in the form of patents, trademarks, designs and utility models registered under the PCT only for patents. We carried out the statistical test under the same conditions and the results are illustrated in Table 2.

\begin{tabular}{|c|c|c|c|c|}
\hline \multicolumn{5}{|c|}{$\begin{array}{l}\text { Dependent Variable: } P \\
\text { Method: Panel EGLS (Cross-section random effects) } \\
\text { Cross-sections included: } 32 \\
\text { Total panel (balanced) observations: } 352\end{array}$} \\
\hline Variable & Coefficient & Std. Error & t-Statistic & Prob. \\
\hline ANNI & $-2.17 E-07$ & 3.22E-08 & -6.738327 & 0.0002 \\
\hline GDP & $-1.80 \mathrm{E}-07$ & 5.10E-08 & -3.536278 & 0.0005 \\
\hline GDP_PC & 0.295618 & 0.129228 & 2.287569 & 0.0228 \\
\hline FDI & -10.08672 & 323.0052 & -0.031228 & 0.9751 \\
\hline$S$ & -85.68106 & 465.7344 & -0.183970 & 0.8541 \\
\hline KOF & 15845.34 & 9774.873 & 1.621028 & 0.1059 \\
\hline
\end{tabular}

Table 2: The results of $\mathrm{P}$ panel regression (own calculation)

Patents are a significant source of revenues (apart from copyright licences) for technically demanding industries. Their influence on profits of companies is visible from the beginning, whether in terms of increasing competitiveness or sales. Private persons particularly benefit from sales.

The results of panel regression in this narrowed model do reject the null hypotheses in contrast to the alternative hypotheses $\mathrm{H} 1, \mathrm{H} 2$ and $\mathrm{H} 3$. The probability of the relation between the quantity of registered patents and the amount of adjusted net national income, gross domestic product and GDP per capita is statistically highly significant. Thus, there is only a small probability for randomness of results.

GDP is a performance indicator that shows a value of all products and services produced by residential entities in the territory of a country for a monitored period (its computation applies the territorial principle). The link found between the values of the indicator and the quantity of registered patents in individual countries suggests that a higher level of intellectual property protection under patents contributes to the performance of domestic economies. The performance of an economy is shown more real by the GDP per capita (GDP_PC). This indicator is proved a lot in practice as it allows us to compare the performance of economies with respect to their size, population (as well as the rate of productive 


\author{
(online) $=$ ISSN $2285-3642$ \\ ISSN-L = 2285 - 3642 \\ Journal of Economic Development, Environment and People \\ Volume 5, Issue3, 2016 \\ URL: http://jedep.spiruharet.ro \\ e-mail: office jedep@spiruharet.ro
}

population). The adjusted net national income (ANNI) indicator is a summary of payments to the owners of production factors. The results of panel regression prove that there is a close link between the quantity of registered patents and the amount of adjusted net national income.

\title{
5. Discussion
}

The protection of intellectual property has its supporters as well as opponents depending on their perspective on the utility and moral aspects of implementing the policy for protection of intellectual property. The positive response may be summarised in four points:

a) It provides protection of innovative activities and discoveries for enterprises in order to create a niche in the market, to enhance the competitiveness and value of enterprises;

b) It provides protection of innovations against illegal copying and use of know-how, original works, and prevents the right holders from losing their revenues earned from their investment;

c) It lets consumers get information on quality and benefits of products and services; and

d) It stimulates investment in research and development and simplifies transfer of innovations from laboratories to the market.

The benefits may also include positive effects of patents on macroeconomic indicators of countries, despite that we did not manage to prove the relation when taking in account other forms of intellectual property. On the other hand, we can similarly summarise the arguments of negative effects of the globalization of intellectual property:

a) It limits the flow of innovations and transfer of technologies, which may cause stagnation;

b) It means a handicap for the less developed countries that do not have enough capacities to influence international treaties and use advantages of intellectual property protection;

c) The protection in the area of pharmaceutical products or biological processes may threaten personal life and health;

d) It enables to create monopolies and deform markets;

e) It creates a number of unused inventions that are stored by enterprises.

However, it actually encourages the society in a global sense to invest efforts and resources in continuous strengthening of the protection system of intellectual property. Who benefits from creating the global regime which each country must be subordinated, under the threat of economic sanctions? 


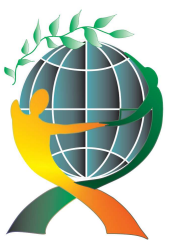

\author{
(online) $=$ ISSN $2285-3642$ \\ ISSN-L = $2285-3642$ \\ Journal of Economic Development, Environment and People \\ Volume 5, Issue3, 2016 \\ URL: $\underline{\text { http://jedep.spiruharet.ro }}$ \\ e-mail: office jedep@spiruharet.ro
}

It is exceptionally difficult to prove a positive influence of the strong protection regime of intellectual property on the prosperity of national economies or society. The usefulness of such protection can only be seen in the private sphere. Beháňová (2008) argues that a strong protection system of intellectual property rights is a driver for innovations, a stimulation of investment in research and development and it makes easier to transfer knowledge from research laboratories to the market. However, the driving force for innovations is profit. Intellectual property is a tool for increasing profits from the intellectual activity that is being implemented in the enterprise's environment, and at the same time it limits the use of a result of the intellectual activity outside the company. The enterprise thus enhances its competitiveness or relatively decreases the competitiveness of the others - it is only a question of a perspective.

On the one hand, scholars declare a decrease in tangible assets in the market value of the companies listed on a stock exchange. Companies focus on intellectual capital that currently accounts for $70-80 \%$ in the financial markets (Straus, 2004). However, on the other hand, lower operational costs, cheap labour costs and more 'flexible' legislation in emerging markets are a greater motivation for localisation of foreign company branches, despite the poor protection regime of intellectual property. International research conducted by Pricewaterhouse Coopers (2007) suggested that almost $70 \%$ of managers consider intellectual property as a legal matter and not as a strategic tool for enterprise development. In the research Jean-Pierre Laisne draws attention to a gradual change in the protection attitude against intellectual property. The efforts to control and strongly protect intellectual property cause inflexibility of the development of innovations in industries. Laisne particularly emphasizes the fact that without a certain level of cooperation the entire industries will suffer. (PricewaterhouseCoopers, 2007, p. 21)

As it is noted by E. Kováč and K. Žigić (2014), competition between companies in developed industrialized countries and companies in less developed countries commonly lies in the vertical differentiation of products. The governments in various countries face dilemmas to what extent they shall leave space for the free market, or how to regulate protection of intellectual property, because the problem of qualitative changes from the perspective of social welfare is becoming prominent, the changes that are connected with the preference of trade policy to free market.

The research outcome published by O. Slivko and B. Theilen (2014) in such a context suggests that protection of intellectual property may have an ambiguous influence. In the markets that have a high rate of innovations, a reduction in protection of intellectual property in a substantial manner may discourage innovation performance. However, a reduction in patent protection may, on the other hand, increase the social welfare because it can induce imitation. That means that the question of setting the patent protection may not be solved without taking into account specific characteristics of specific markets and companies that compete in the market. 


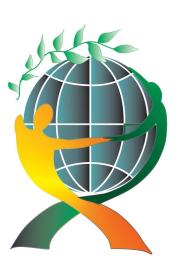

\author{
(online) $=$ ISSN $2285-3642$ \\ ISSN-L = $2285-3642$ \\ Journal of Economic Development, Environment and People \\ Volume 5, Issue3, 2016 \\ URL: http://jedep.spiruharet.ro \\ e-mail: office jedep@spiruharet.ro
}

Firstly, the strong protection regime of intellectual property is inevitable for companies whose intellectual assets become the primary source of revenue and profit generation. ${ }^{1}$ since economy is currently developing towards 'intellectual capitalism', intellectual property is experiencing the beginning of its boom. On the one hand, the protection of such ownership has a really stimulating effect - is enough to think to the productivity of corporations concentrated in Silicon Valley, whose revenues are higher than revenues of many national economies.

However, the strong protection regime often has a counterproductive effect. It prevents, for example, small software companies from succeeding in the market because each algorithm, elementary command and programme has already been patented or copyrighted, which hinders the development of new applications and software. The USA is a country with the strongest protection regime of intellectual property which provides protection to the largest portfolio of ideas and inventions. In the US market there is a similarly developed system of exercising and enforcing intellectual property rights. However, such an over-exposed regime often leads to absurd situations in which individuals in pursuit of profit compete in registering literally any ideas, for instance, patents registered for a human head bird feeder, collector of human and animal bodily gasses, portable human noise silencer, etc., or even stealing from foreign cultures, for example, in the form of registering products made of medicinal herbs that, in certain cultures, have been in use for hundreds or thousands of years.

The entire process of ensuring protection of intellectual property is difficult for ordinary individuals, especially in terms of time and administration. The individuals in countries and regions with developed markets, for example, the USA and the EU countries, have an advantage. Most information on protection provision is in English, which handicaps countries with population of poorer language literacy. In many countries the population is not aware of intellectual property opportunities; there are no relevant authorities with competent and professional staff, no information centres, no enforcement of rights.

Trademarks are a specific aspect of intellectual property protection. Many companies sell goods manufactured in the countries with cheap labour and poor enforcement of intellectual property rights. The products of famous sporting and fashion brands or brands of international fashion designers originate exactly in those countries. The same producer often manufacture the products of a lower quality, or even of the same quality, which are sold on the black market for a fraction of the price. According to Beháňová (2008) the trade with plagiarism, including clothing, medicaments, electrical appliances, food, software, etc., accounted for almost 6\% of the world trade (i.e. 456 billion USD) in 2003.

\footnotetext{
${ }^{1}$ A study conducted by PriceWaterhouse Coopers (2007) cited H. Gutierrez who says that Microsoft is an IT corporation which invests over 7 billion USD a year in research and development and the results transferred in intellectual property generate licensing revenues for Microsoft. Apple, which earns revenues not on hardware production but rather on selling software components, i.e. intellectual property, has the same attitude to intellectual property.
} 


\author{
(online) $=$ ISSN $2285-3642$ \\ ISSN-L = $2285-3642$ \\ Journal of Economic Development, Environment and People \\ Volume 5, Issue3, 2016 \\ URL: http://jedep.spiruharet.ro \\ e-mail: office jedep@spiruharet.ro
}

\title{
6. Conclusions
}

The globalization process of intellectual property had been around for several decades. The globalization is, in this case, the main stimulus and tool for expanding the protection regime of intellectual property that is characteristic of rather economically developed countries in the European and North American continent.

Intellectual property is often handled as something monolithic, without any differentiation among the effects of its different forms (e.g. patent, trademark, design, utility models, which are included in our empirical test). These forms have their own different regulations, and therefore their effects also diverge. It is clear that there are common problems (i.e. the problems of property and ownership over the information) but the most important effects are specific. Inter alia, the most important incentives for innovation come from the patent system - or more precisely, from the income generated through the patent system; the incentive to assure the quality of the products results from the trademark; the patent has stronger influence on market structure and on the cost of further research. But all of these effects depend heavily on the exact form of regulation (e.g. the length and the breadth of the protection and on the possibility of compulsory licensing, etc.). The empirical research presented in the paper itself finds different effects - the patents seem to have a stronger influence on macro indices than other forms of intellectual property.

First we tried to analyse the diversity of views on the subject of intellectual property protection and its globalization on the basis of our own research. The outcome of testing statistical hypotheses did not suggest the existence of a statistically significant dependence between the quantity of registered intellectual property, macroeconomic indicators and the KOF globalization index. In our research we focused on countries that have similar systems for protecting intellectual property under the forms that the effective legislation enables to exercise and protects to a similar extent. On the other hand, however, each form of intellectual property protection has a different dimension, purpose and consequences. For these reasons we retested the statistical hypotheses we formed under the same conditions, and we narrowed the explained variable only for protection of intellectual property in the form of patents. With such an adjustment to the tested model, we came to the conclusion that there is a statistically significant probability of existence of the relation between the quantity of registered patents and the level of gross domestic product (GDP), gross domestic product per capita (GDP_PC) and adjusted net national income (ANNI).

However, there are still many unanswered questions remaining for researchers, about the implications of globalization of intellectual property for some countries, and the effort to clarify them is hindered by failure to harmonise the systems of intellectual property protection in individual countries.

The biggest challenges to copyright, that appear automatically, without being registered, and therefore it is not possible that their quantitative and qualitative development to be followed. Serious noncompliance is caused by software which is, in some countries protected as copyright, whereas elsewhere it 




\author{
(online) = ISSN $2285-3642$ \\ ISSN-L = 2285 - 3642 \\ Journal of Economic Development, Environment and People \\ Volume 5, Issue3, 2016 \\ URL: http://jedep.spiruharet.ro \\ e-mail: office jedep@spiruharet.ro
}

is protected under patent. Software and computer programmes have a significant share in the market of intellectual property. Similarly, the meaning of trademark is controversial since its importance is paralysed by the continuous growth of the shadow economy.

In general, it can be noted that the global intellectual property protection regime that is becoming stronger and stronger is often the reason for expansion of the black market and infringement of intellectual property rights. In such a context the inspiration for improved use of creative results of intellectual activity can be found in effectively functioning clusters, the concept of open innovations and different forms of cooperation between private and public entities in the innovation process.

\title{
7. References
}

[1] Agreement on Trade-Related Aspects of Intellectual Property Rights (TRIPS),1995, [Online] at https://docs.wto.org/dol2fe/Pages/FE_Browse/FE_B_009.aspx, accessed March 15th, 2016.

[2] D. Archibugi, and A. Filippetti. The Globalisation of Intellectual Property Rights: Four Learned Lessons and Four Theses. Global Policy 2010, 1(2): 137-149.

[3] J. Baylis, and S. Smith, et al. The Globalization of World Politics. Oxford University Press, 2008.

[4] M. Beháňová. Duševnévlastníctvo v globalizovanomsvete.Logistický monitor 12/2008, [Online] at http://www.logistickymonitor.sk/en/images/prispevky/dusevne-vlastnictvo.pdf, accessed January 10th, 2016.

[5] T. Dobřichovský. Moderní trendy práv k duševnímuvlastnictví. Linde, 2004.

[6] V. Dudinský, and I. Dudinská. Globalizáciaajakoteoretickýproblém (niekol'kopoznámoknamargo).In:Globalizácia a vzdelávanieučitelov. Bratislava: Comenius University. 2012, pp. 118-124.

[7] Z. Hajnalová. Ochranaoznačenípôvoduvýrobkov a zemepisnýchoznačenívýrobkovnaSlovensku a v zahraničí. In: Zborník z konferencieDuševnévlastníctvonaSlovensku IX (k svetovémudňuduševnéhovlastníctva). BanskáBystrica: ÚPV SR. 2009, pp. 17-23.

[8] International Monetary Fund (online database), [Online] at http://www.imf.org, accessed April 12th, 2016.

[9] C. Juma. Intellectual Property Rights and Globalisation: Implications for Developing Countries. In: Science, Technology and Innovation Discussion Paper No.4. Cambridge: Center for International Development, Harvard University. 1999, [Online] at http://www.cid.harvard.edu/archive/biotech/papers/discuss4.pdf, accessed February 20th, 2016.

[10] KOF Index of Globalization, [Online] at http://globalization.kof.ethz.ch/, accessed March 11th, 2016.

[11] E. Kováč, and K. Žigić. International Competition in Vertically Differentiated Markets with Innovation and Imitation: Trade Policy Versus Free Trade.Economica 2014,81(323): 491-521.

[12] Ch. Oguamanam. IP in global governance: a venture in critical reflection. WIPO Journal 2011, 2(2): 196-216.

[13] Patent Cooperation Treaty (PCT), [Online] at http://www.wipo.int/export/sites/www/pct/en/texts/pdf/pct.pdf, accessed January 5th, 2016.

[14] PricewaterhouseCoopers: Exploiting intellectual property in a complex world. Technology executive connections 20074(6) [Online] at http://www.pwc.com/en_gx/gx/technology/pdf/exploiting-intellectual-property.pdf, accessed June 4th, 2016. 


\author{
(online) $=$ ISSN $2285-3642$ \\ ISSN-L = $2285-3642$ \\ Journal of Economic Development, Environment and People \\ Volume 5, Issue3, 2016 \\ URL: http://jedep.spiruharet.ro \\ e-mail: office jedep@spiruharet.ro
}

[15] O. Slivko, and B. Theilen. Innovation or imitation? The effect of spillovers and competitive pressure on firms' R\&D strategy choice. Journal of Economics 2014, 112(3): 253-282.

[16] J. Straus. Patentováochranapodl'adohody TRIPS. Výnimočnéúpravy, ichprax a význam s osobitnýmzretel'omnafarmaceutickévýrobky. Duševnévlastníctvo 2004, 8(4): 6-14.

[17] The World Bank (online database), [Online] at http://data.worldbank.org, accessed February 1st, 2016.

[18] ÚradpriemyselnéhovlatníctvaSlovenskejrepubliky, [Online] at http://www.indprop.gov.sk, accessed April 1st, 2016.

[19] World Intellectual Property Organisation (online database), [Online] at http://www.wipo.int, accessed February 7th, 2016.

[20] World Trade Organisation (online database), [Online] at https://www.wto.org/, accessed February 3rd, 2016. 